

\title{
O Desenvolvimento para Além dos Arranjos Produtivos Locais (APLs): uma Exploração no Norte Fluminense
}

\author{
Development Beyond Local Productive \\ Arrangements (APLs): An Exploration \\ in North Fluminense
}

\author{
Lia Hasenclever* | Yves Fauré** | Caroline Miranda***
}

\section{Resumo}

O objetivo do artigo é avaliar a formulação e a implementação da Política de Arranjos Produtivos Locais (APLs) a partir de dois estudos de caso municipais da região norte fluminense - Campos dos Goytacazes e Macaé, no período 2002 a 2016. A metodologia adotada analisa indicadores quantitativos e qualitativos do crescimento e do desenvolvimento econômico e humano dos municípios e, a seguir, a partir de pesquisa bibliográfica e investigações de campo, os três setores da região contemplados com a marca APL. Os resultados mostram que, apesar do crescimento econômico dos municípios de 2002 a 2014, os setores de fruticultura irrigada e de cerâmica em Campos, e de petróleo e gás em Macaé não foram capazes de mudar a estrutura econômica local ou melhorar o bem-estar da população. O estudo ilustra os limites da Política de APLs e a importância dela ser repensada de forma integrada a outros setores da região e nacionais.

Palavras-chave: crescimento econômico; desenvolvimento econômico e humano; política de arranjos produtivos locais; Campos; Macaé.

\begin{abstract}
The objective of the article is to evaluate the formulation and implementation of the Local Productive Arrangements Policy (APLs), based on two municipal cases studies in the northern region of Rio de Janeiro - Campos dos Goytacazes and Macaé, in the period 2002 to 2016. The methodology adopted analyzes quantitative indicators and qualitative of the economic and human growth and development of the municipalities and, afterwards, from bibliographic research and field investigations the three sectors of the region covered with the APL brand. The results show that despite the economic growth of the municipalities from 2002 to 2014, the sectors of irrigated fruit and ceramics in Campos, and oil and gas in Macaé were not able to change the local economic structure or improve the well-being of the population. The study illustratesthe limits of the APL Policy and the importance of it being rethought in an integrated manner to other sectors in the region and nationally.
\end{abstract}

Keywords: economic growth; economic and human development; policy of local productive arrangements; Campos; Macaé.

\footnotetext{
* Professora Colaboradora da Universidade Cândido Mendes - Campos dos Goytacazes e pesquisadora associada do Instituto de Economia da Universidade Federal do Rio de Janeiro. https://orcid.org/0000-0003-1384-6323. E-mail: lia@ie.ufrj.br

** Institut de Recherche pour le Développement - IRD, UMR Prodig, Universidade Paris 1. https://orcid.org/0000-0001-8042-3553. E-mail: yafaure@yahoo.fr

*** Caroline Miranda: Aluna de doutorado do Programa de Pós-Graduação em Políticas Públicas, Estratégias e Desenvolvimento da Universidade Federal do Rio de Janeiro. https://orcid.org/0000-0001-7126-2348.

E-mail: carol_miranda91@hotmail.com.
}

Recebido em 9 de abril de 2020. Aceito em 30 de julho de 2020. http://dx.doi.org/10.51861/ded.dmv.2.015 


\section{INTRODUÇÃO}

A partir de 2004 e ao longo de dez anos, a Política de Arranjos Produtivos Locais (APLs) e seus programas envolveram várias instituiçôes políticoadministrativas e financeiras e formaram a base da política de desenvolvimento brasileiro. Inúmeros objetivos desde os mais modestos, como valorizar as tradições locais, até os mais ambiciosos, como estimular o empreendedorismo e inovar, compunham o rol de ações da Política. É, segundo Bacelar (2013), uma política de desenvolvimento regional de base territorial clara, entretanto, com definição muito ampla de objetivos e uma enorme dificuldade de governança entre os vários órgãos federais envolvidos e o Serviço Brasileiro de Apoio às Micro e Pequenas Empresas (Sebrae) ${ }^{1}$. Sua concepção prevê iniciativas ligadas às próprias regióes e o papel do governo federal é apenas o de apoiá-las. Ainda segundo a autora, as clássicas políticas regionais explícitas, aquelas voltadas claramente para enfrentar a questão de desenvolvimento regional desigual do país, não tiveram grande prioridade no período, sendo substituídas pela Política de APLs.

Uma grande quantidade de estudos, documentos técnicos, artigos e livros foram dedicados aos APLs, alguns formulando apreciaçóes positivas e outros expressando uma visão mais crítica. Não é objetivo de o artigo fazer uma revisão bibliográfica desses estudos, mas somente para ilustrar pode-se citar autores com visóes positivas, os quais consideravam que os APLs poderiam ser instrumentos do desenvolvimento regional e do desenvolvimento industrial,ambas as orientações até então negligenciadas pelas políticas econômicas neoliberais (SADER, 2013; LASTRES et al., 2006). Outros autores,com visão mais crítica, evidenciavam o fracasso destas ambiçôes, explicado segundo Carleial (2014, p. 11)“... porque, na economia mundializada, com forte presença da firma-rede multinacional, as atividades fazem-se e articulam-se em diferentes escalas espaciais"e não apenas na escala local, como pressuposto na Política de APLs. Além disso, o Banco Nacional de Desenvolvimento Econômico e Social (BNDES), principal instituição financeira envolvida nesta política, ancorou sua visão regional nos APLs e, com isso, empobreceu a problemática do desenvolvimento regional e suas potencialidades de realização, como tinha sido sua atuação nas décadas de 1950 a 70 .

Quanto à perspectiva de industrialização através dos APLs, Schmidt Filho e de Paula (2008, p. 01) escreveram: “...essas politicas [de APLs] estão mais próximas de uma politica social regional de distribuição de renda do que propriamente de uma politica industrial"

O objetivo deste artigo é aprofundar esta avaliação da política de APLs por meio de dois estudos de casos municipais. Especificamente,explorar o crescimento e o desenvolvimento econômico e humano de: Campos dos 
Goytacazes e Macaé, localizados na Região Norte Fluminense, Estado do Rio de Janeiro (ERJ) e de seus três APLs beneficiados pela Política, assim como as relações destes com as economias locais. Parte-se do princípio que, de um lado, as economias locais são influenciadas por fatores externos macro e meso e que, de outro lado, vários setores relacionados, além dos setores selecionados pela Política de APLs, animam as atividades na escala local. Entende-se que as economias locais não são autônomas, pois dependem de outros fatores externos, enem podem ser reduzidas à atuação e aos efeitos eventuais das políticas localizadas de APLs quando almejam o desenvolvimento econômico e humano.

A metodologia adotada pode ser dividida em duas etapas. Na primeira, apoia-se em algumas ferramentas básicas e consensuais do corpus da economia do desenvolvimento ${ }^{2}$ para analisar a situação econômica e social dos dois municípios. Assim, indicadores quantitativos como Produto Interno Bruto(PIB) e PIB per capita e qualitativos como o Índice Firjan de Gestão Fiscal (IFGF) e o Índice Firjan de Desenvolvimento Municipal (IFDM), ambos da Federação das Indústrias do Estado do Rio de Janeiro (Firjan) foram utilizados para identificar e diferenciar o crescimento do desenvolvimento econômico e humano.

As bases estatísticas do Instituto Brasileiro de Geografia e Estatística (IBGE) sobre os PIBs municipais e a Classificação Nacional de Atividades Econômicas (CNAE), da Relação Anual de Informações Sociais (RAIS) sobre emprego e estabelecimentos foram as fontes de pesquisa para as estatísticas quantitativas.

Quanto aos Índices mencionados, além de fornecer para cada município seu ranking estadual e nacional eles permitem uma avaliação qualitativa dos municípios. O IFGF avalia os resultados dos municípios em termos de gestão dos seus orçamentos. As fontes utilizadas são os documentos entregues pelas prefeituras à Secretaria do Tesouro Nacional. Cinco conjuntos de indicadores são levados em conta e explorados: receita própria, gastos com pessoal, investimentos, liquidez e custo da dívida. A base do IFDM é constituída pelos dados do Ministério do Trabalho e Emprego, do Ministério da Educação e do Ministério da Saúde. O IFDM acompanha o desenvolvimento socioeconômico dos municípios brasileiros a partir de três indicadores: emprego/renda, educação e saúde ${ }^{3}$.

$\mathrm{Na}$ segunda etapa da metodologia, as diversidades das situaçóes locais foram o foco, utilizando-se um método indutivo (Fauré e Hasenclever, 2007). Os instrumentos utilizados nesta etapa foram visitas exploratórias, observaçốes e investigações feitas in situ com o uso de guias de entrevistas, bem como leitura de documentos específicos. As entrevistas foram realizadas 
com vários protagonistas dos arranjos produtivos estudados e com as instituições responsáveis pela aplicação das políticas. Os dados levantados foram analisados em contraponto ao desempenho socioeconômico dos municípios frente às escalas estaduais e nacionais, resultantes da primeira etapa da metodologia.

O artigo está organizado em três seçôes, além dessa introdução e da conclusão. $\mathrm{Na}$ primeira seção, o crescimento e o desenvolvimento dos dois municípios no período de 2002 a 2016 são apresentados. Na segunda seção, dedicada especificamente aos três APLs oficializados pela Política de APLs nos dois municípios estudados, são descritos os resultados da pesquisa de campo em perspectiva com estudos anteriores já realizados. Finalmente, na terceira seção discutem-se os resultados verificando em que medida o desempenho dos APLs e do crescimento e desenvolvimento econômico e humano locais permitiram ou não uma maior sinergia e uma melhoria do bem-estar da população. Ainda nesta seção, especula-se com possíveis linhas de estratégias de desenvolvimento mais promissoras para ambos os municípios.

\section{CRESCIMENTO E DESENVOLVIMENTO DOS MUNICÍPIOS DE CAMPOS E MACAÉ}

O pensamento sobre a economia do desenvolvimento (incluindo crescimento) está longe de ser monolítico; deu origem a muitas controvérsias expressas por diferentes autores, correntes e escolas. Podem-se mencionar seletivamente as oposiçóes entre o crescimento equilibrado e o desequilibrado, as diferenças entre as abordagens estruturalistas e as abordagens institucionalistas, as divergências entre o planejamento rígido e o planejamento indicativo, a arbitragem entre investimentos em infraestruturas econômicas e sociais e investimentos em atividades diretamente produtivas.

Os elementos aqui utilizados deste corpus rico e prolixo são os mais consensuados pela literatura sobre o tema e buscam deixar claro as reflexóes sobre as eventuais ligaçóes entre APLs, crescimento e desenvolvimento. $\mathrm{O}$ crescimento econômico refere-se ao aumento, durante um período mais curto ou mais longo, da quantidade de bens e serviços produzidos em um determinado território. É chamado de extensivo quando é proporcional ao aumento das quantidades dos fatores de produção e é chamado intensivo quando relacionado ao aumento da produtividade do trabalho e/ou capital. Essa última forma é a mais desejada, pois permite a sustentabilidade do processo de crescimento.

O crescimento econômico é fonte de aumento de renda e emprego, mas não melhora automaticamente o bem-estar da população desse 
território. Em sentido estrito, o crescimento diz respeito exclusivamente à produção econômica. A diferença com a noção de desenvolvimento econômico é que ela corresponde a mudanças estruturais econômicas e sociais (SCHUMPETER, 1997; PERROUX, 1990). O desenvolvimento referese, portanto, a um conjunto de mutações positivas, técnicas, demográficas, sociais, e de saúde públicade uma localidade, região ou país. Essas mutações trazem uma melhoria no bem-estar social que envolve uma noção multidimensional. Amartya Sen acrescentou ainda a perspectiva do desenvolvimento humano e a importância das capabilities dos indivíduos, isto é, suas capacidades de exercerem plenamente seus direitos de acesso a serviços públicos.

O relatório do Programa das Naçóes Unidas para o Desenvolvimento (PNUD) de 1996 confirmou que não há ligação automática entre crescimento ou desenvolvimento econômico e desenvolvimento humano. Em suma, se o objetivo é alcançar o desenvolvimento humano e econômico será necessário a realização de políticas estruturantes. Em outras palavras, baseadas em uma vontade, uma estratégia e um projeto político de transformação, resultado de várias decisôes de distintos atores coordenados e orientados por uma autoridade central (governança). A capacidade de investimento é a força motriz do crescimento e do desenvolvimento econômico. Mas, as noçôes de complementaridade, de multiplicador, de encadeamento, de ligaçóes a montante e a jusante, de externalidades positivas, todas associadas ao investimento implicam o desenho de políticas para coordenar esses processos e impedir a concentração de seus ganhos sem melhorias no bem-estar da população.

Se, como apontado na introdução a Política de APLs não continha em sua formulação esses requisitos estruturantes e de governança, pode-se tomar como hipótese que ela dificilmente poderia resultar em desenvolvimento local. A seguir, utilizam-se alguns instrumentos e indicadores clássicos da literatura de crescimento e de desenvolvimento para verificar até que ponto, nas duas economias municipais estudadas, o contexto econômico e social em que os APLs estão involucrados permitiram ou dificultaram o avanço rumo ao crescimento e/ou ao desenvolvimento econômico e humano.

\section{O crescimento e o desenvolvimento perdidos no passado recente}

A evolução dos PIBs municipais mostra duas fases opostas: em Campos, o PIB de 2002 até 2012 apresentou um coeficiente multiplicador de 4,76contra um coeficiente de 3,12 do ERJ. Em seguida, observamos uma importante queda que fez com que o PIB municipal de 2016 alcançasse apenas um terço do pico de 2012. Em Macaé, o PIB aumentou até 2014 com um coeficiente de 4,23 em relação a 2002 e depois baixou até um coeficiente de 3,48 em 2016. 
O clima desfavorável, no fim da sequência observada, foi acentuado pelos novos e repentinos constrangimentos orçamentários dos municípios, limitando as possibilidades de ações das prefeituras. As receitas orçamentárias totais de Campos aumentaram regularmente para apresentar um coeficiente de 5,26 de 2002 a 2014, e depois baixaram até um coeficiente de 4,97 em 2016. Se as transferências da União e do ERJ diminuíram entre 2014 e 2016, o principal fator explicativo da queda das receitas foi a redução drástica da arrecadação dos royalties e das participaçóes especiais. Estes, que representavam em torno de $70 \%$ das receitas correntes nos anos 2000, não pararam de diminuir, alcançando uma participação de 19,2\% em 2016. As tendências foram mais ou menos as mesmas no orçamento da prefeitura de Macaé: o coeficiente de aumento foi de 6 vezes em 2016 comparativamente a 2002, mas de 2014 a 2016 houve uma queda de 10,3\%. Enquanto as transferências da União e do ERJ se mantiveram, a arrecadação dos royalties diminuiu: elas representavam mais da metade das receitas correntes nos anos 2000 e apenas 15,2\% em 2016 (TCE, 2002-2016).

As mudanças com efeitos questionáveis das estruturas produtivas municipais

A análise da evolução de 2002 a 2016 dos componentes de atividades econômicas dos respectivos PIBs revela algumas mudanças nas características das economias locais. Ao longo do período examinado, Campos se tornou um município com fortes atividades de serviços - tanto privados quanto públicos, que representavam cerca de $34,5 \%$ do PIB municipal, em 2002, e atingiram o nível de $64,1 \%$ em 2016 , em detrimento das atividades industriais que representavam até $75 \% \mathrm{da}$ base produtiva campista nos primeiros anos do período, contra 30\% em 2016. Em Macaé, a indústria que representava 47,3\% do PIB em 2002 passou a representar 26,9\% em 2016, principalmente por causa da crise do petróleo. No município, o conjunto privado e público das atividades de serviços representaram 38,3\% do PIB em 2002 e 60\% em 2016.

Desta forma, se de um lado podemos constatar que a estrutura das economias locais dos principais municípios do norte fluminense, Campos e Macaé, se aproximaram dos movimentos registrados nas escala estadual e até nacional, com a preponderância dos serviços, por outro lado, o processo de desindustrialização dita "precoce" do Brasil também se manifestou. Este resultado não é vantajoso, pois a literatura econômica alerta sobre a importância da indústria para o desenvolvimento, já que o setor favorece mais as inovaçóes e encadeamentos com outros setores do que o de serviços, em que predomina o comércio de circulação de mercadorias e não a sua real transformação. 
As inércias na distribuição de estabelecimentos e de emprego

Apesar de o número de estabelecimentos ter aumentado de 5.875 , em 2002, para 8.754 em 2016, em Campos, e de 2.858 para 4.925, nos mesmos anos, em Macaé, a distribuição dos estabelecimentos por setores de atividades ficou muito pouco alterada ao longo do período em ambos os municípios (RAIS, 2002-2016).

No que diz respeito à distribuição do emprego, pode-se constatar em Campos uma quase reprodução do emprego por setor de atividade entre 2002 e 2016. A exceção é a indústria de transformação que passou de $12 \%$ do total do emprego em 2002 a 6\% em 2016: este resultado não é a consequência de uma dinâmica superior dos outros setores, pois em termos de dados absolutos Campos perdeu muito postos de trabalho neste segmento da economia. Em Macaé, alguns setores aumentaram o seu peso relativo na composição do emprego total entre 2002 e 2016, por exemplo, o transporte ( +5 pontos percentuais), a administração pública $(+5)$ e, sobretudo, o setor da saúde pública e dos serviços sociais $(+67 \%)$, enquanto outros setores contribuíram negativamente, como a indústria extrativa $(-5)$ e as atividades burocráticas privadas $(-8,3)$.

Tanto em termos de PIB e da sua composição, quanto em termos da composição setorial de estabelecimentos e de emprego é difícil constatar, nas economias campista e macaense,que tenha havido transformações estruturais notáveis, um pressuposto do desenvolvimento econômico.

Uma avaliação qualitativa do desempenho dos dois municípios

A evolução do IFGF dos dois municípios de 2002 a 2016 revela uma queda significativa de desempenho na gestão de seus orçamentos. Esta tendência negativa no final do período pode ser explicada tanto pela repercussão da crise econômica nacional na escala local quanto pelas dificuldades do setor petrolífero do qual dependem muito os dois orçamentos municipais. As fracas performances dos últimos anos envolvem muitos municípios além daqueles estudados aqui. Desta forma, o município de Campos ganhou uma posição na colocação entre os municípios fluminenses ao longo dos anos. Ao contrário de Macaé que perdeu 11 posiçôes no mesmo período, resultados péssimos, tanto intrínsecos como também relativos, decorrentes de sua maior especialização em petróleo.

Tratando-se do IFDM geral, observa-se que, entre 2002 e 2016, o índice de Campos melhorou em 7,2\%, enquanto o de Macaé caiu 9,4\%. Os dois municípios, entretanto, perderam várias posições no ranking estadual (Campos 5 , Macaé 16), o que demonstra que as performances médias dos municípios do 
ERJ foram acima das dos dois municípios, o que pode estar indicando que a dependência do petróleo trouxe crescimento, mas não desenvolvimento, já que o índice infere tanto no crescimento quanto no desenvolvimento ${ }^{4}$.

Os resultados dos dois municípios entre 2002 e 2016 mostram uma queda importante na área de emprego e de renda: - 8,9\% em Campos, -36,8\% em Macaé. Se Campos aumentou oito posições, Macaé perdeu 23 posições no ranking estadual, pois vários outros municípios do ERJ resistiram melhor à crise econômica geral. $\mathrm{Na}$ área da educação, os dados de 2016 revelam melhorias nos dois casos: Campos $+22,7 \%$, Macaé $+10,9 \%$. Mas, na medida em que os desempenhos dos demais municípios fluminenses foram superiores à dos dois municípios analisados, esses perderam espaço: Campos -2 colocações, Macaé -13. Por fim, na área da saúde as performances são contrastadas: Campos aumentou o seu índice em 9,8\%, enquanto Macaé piorou em $0,5 \%$. Estes resultados individuais explicam o rebaixamento relativo dos dois municípios: Campos -14 colocaçôes, Macaé -13.

Para resumir todos estes resultados, tanto em função do IFGF quanto do IFDM, o posicionamento relativo dos dois municípios no conjunto de todos os municípios fluminenses revelou perda de posiçóes, indicando um não espraiamento para o desenvolvimento humano.

Em parte, pode-se atribuir este resultado à importância dos recursos recebidos pelos dois municípios, a partir dos royalties e de participaçóes especiais. De certa maneira, eles não ajudaram as prefeituras a planejarem políticas locais de direcionamento destas rendas e até podem parecer uma desvantagem em relação a outros municípios que não se beneficiaram destes repasses do petróleo. O recebimento abundante dessas rendas, decorrente da exploração de recursos naturais, funcionou como uma espécie de armadilha, ou seja, o que a literatura denomina de doença holandesa (dutch disease), termo que indica o desestímulo ao investimento na indústria, prejudicando o desenvolvimento.

\section{AS VICISSITUDES DOS TRÊS APLS}

É possível identificar três dimensões ou significados do termo APL: (i) é uma marca, um selo, concedido por órgãos oficiais em favor de algumas concentrações locais de atividades que têm, a priori, um forte potencial de crescimento e que, por isso, merecem atenção e apoio; (ii) pode ser beneficiada por programas de ações enquanto designada como APL; (iii) por fim, é um conjunto produtivo real e concreto, local, que pode evoluir graças aos apoios recebidos ou independentemente da manutenção ou não da marca $\mathrm{APL}^{5}$. 
As trajetórias dos APLs de Campos

No estudo minucioso, dedicado até a metade dos anos 2000 à economia de Campos dos Goytacazes, La Rovere e Carvalho (2005) lembraram que durante muito tempo as atividades do município eram relacionadas ao complexo sucro-alcooleiro e que, já a partir de 1998, elas se reduziram inexoravelmente. E, se o setor agropecuário na participação do PIB local se manteve um pouco acima do mesmo setor no PIB fluminense, o crescimento das atividades industriais foi limitado pela proximidade do estado do Espírito Santo que, na época, praticava uma política eficaz de incentivos fiscais para atrair novas plantas industriais. A perda de contribuição ao PIB municipal entre 1996 e 2001 de 9,2\%, expressava os principais desafios econômicos da cidade à véspera da chegada dos programas de APLs, que supostamente trariam uma nova dinâmica à região campista.

No início dos anos 2000, no município de Campos foram recenseados cinco projetos de apoio às atividades industriais e 12 projetos de apoio às atividades de base agrícola (agropecuária e agricultura irrigada), propostos por vários entes e esferas (privados e públicos) para ajudar o desenvolvimento e a melhoria dos cultivos de frutas. Constatou-se, por meio das entrevistas realizadas em 2019 que, a maioria destes projetos, dificilmente sobreviveu, e, quando foi o caso, foram perdendo o fôlego, como mostra a subseção a seguir.

\section{O APL Frutificar ${ }^{6}$}

Poderosa no setor agropecuário, e particularmente na produção de canade-açúcar, a economia da região campista, já afetada pelas turbulências financeiras do país, enfrentou uma grave crise sucro-alcooleira no final dos anos 1990, com a redução drástica e até o desaparecimento do programa Pro-álcool. A cadeia campista de produção de cana-de-açúcar e de álcool sofreu tanto que, enquanto 19 usinas atuavam nos anos 1970, apenas cinco funcionavam em 2004. Os projetos de irrigação, que na época eram de escala nacional, pois as autoridades federais visavam o aumento da produtividade agrícola e o alcance do mercado internacional, eram direcionados a vários subsetores agrícolas. O governo estadual, a Firjan e alguns órgãos especializados no apoio e no acompanhamento da agricultura consideravam que o desenvolvimento da produção irrigada, cana-de-açúcar e produção de frutas, podia se tornar a base da reconversão, pelo menos parcial, da região.

A substituição da agricultura tradicional seria um instrumento pertinente da sua revitalização na medida em que havia uma série de fatores positivos: condições de clima e solo favoráveis, consumidores domésticos e 
estrangeiros cada vez mais comprando frutas tropicais, localização estratégica da região em termos de transportes e de logística, presença de infraestrutura com qualidade. Todos estes pontos favoráveis justificavam colocar em prática programas de ação associando a fruticultura irrigada à agroindústria. Este processo elevaria o nível tecnológico na esfera produtiva, aumentaria consideravelmente o valor agregado do setor primário como a renda regional e, consequentemente, iria pôr fim ao êxodo rural (Meirelles Junior, 2015).

Assim, foram concebidos, formalizados e lançados dois programas com enfoque na fruticultura irrigada (além do programa Rio Cana): o programa Moeda Verde-Frutificar das autoridades estaduais - na época o governador era ex-prefeito de Campos e a região constituía a sua base eleitoral - e o projeto Frutificar da Firjan, que seguia um estudo prévio encomendado por este órgão que identificava a fruticultura irrigada como uma importante vocação regional. $\mathrm{Na}$ sequência, e com base nestas informações, não foi surpreendente que o polo da fruticultura de Campos se tornasse um APL, marca que devia, normalmente, consolidar e aumentar os recursos e os meios de apoio em prol do polo, o distinguindo de uma aglomeração qualquer de atividade.

Em 2014, a Firjan informava que o Programa Frutificar envolvia em torno de 1.000 produtores na região - bem além do município de Campos. Mas, Meirelles Junior (2015) contou apenas 13 agricultores ativos no projeto. O mesmo pesquisador "...não verificou nas entrevistas uma ação que objetivasse a integração dos produtores da região...” (ibidem, p. 160).

O cultivo de abacaxi se tornou a principal produção, mas a falta de qualidade e o tamanho das frutas não favoreceram uma comercialização lucrativa. Um dos entrevistados, em 2019, acrescentou que o abacaxi produzido localmente não cabia na máquina de processamento da empresa integradora, forçando essa a comprar as frutas em Tocantins. As produções de maracujá e de goiaba diminuíram (Meirelles Junior,2015). As falhas no manejo das culturas fizeram com que o programa convidasse um professor da Universidade Federal de Viçosa (UFV), de Minas Gerais, para orientar os agricultores, sobretudo na produção de abacaxi. Não se pode esquecer ou subestimar um fator limitante de produção e produtividade que é o fator fitossanitário: cada tipo de plantio e de frutas foi acometido de pragas e doenças diversas.

Os atores do setor e outros entrevistados, em 2019, lamentaram que o Programa Frutificar tivesse sido concebido e colocado em prática sem levar em conta a cultura rural local, as opinióes dos agricultores e as práticas deles. Essas eram bem diferentes da produção irrigada, ou seja, se tratava de um projeto imposto de cima para baixo $($ top - down). Daí os problemas encontrados já no início e no decorrer do Programa. Um dos resultados não 
esperados, e até contrário ao espírito deste tipo de programa, foi que os atravessadores se tornaram parceiros nas vendas das frutas com o risco de "manipulação" de preços.

Inicialmente celebrada como empresa âncora do processamento de frutas e gerando muitas esperanças para contribuir à expansão da nova cadeia local, a Bela Joana se destacou já no início do projeto como a principal empresa de processamento de frutas em Campos contratando em torno de 100 empregados e faturando mais ou menos $\mathrm{R} \$ 10$ milhóes (Britto,2004). Mas, esta empresa enfrentou vários problemas e encerrou as suas atividades em torno de 2010, devido às dificuldades para escoar os produtos que já não tinham boa aceitação pelo mercado. Em seguida, a planta industrial foi arrendada e reinaugurada em 2013 e voltou a funcionar, mas sem processar frutas locais. Com um nome novo (Unidrinks, estabelecimento local da Fábrica de Sucos da Arbor Brasil), a planta utilizava nos últimos anos polpa de frutas provenientes de outros estados brasileiros (MEIRELLES JUNIOR, 2015).

Apesar dos financiamentos disponíveis, muitos deles não foram mobilizados. O polo podia ainda se beneficiar da ajuda de um conjunto de quadros e técnicos qualificados da Empresa de Assistência Técnica e Extensão Rural RJ (Emater-Rio) e das estações experimentais da Empresa de Pesquisa Agropecuária do Estado do Rio de Janeiro - Pesagro-Rio (BRITTO, 2004). As entrevistas, entretanto, confirmaram a dificuldade para integrar os programas de irrigação por falta de agentes e técnicos para o aprendizado dos produtores que tinham origem na produção de cana.

A fraca trajetória do APL, pelo menos da sua fase "industrial" pode ser resumida por alguns dados quantitativos. No município de Campos, o número de estabelecimentos formais pertencentes à categoria "fabricação de conservas de frutas” oscilou de 2 a 4 entre 2002 e 2016 com um pico de 5 em 2006 e em 2009. Na mesma categoria de atividade econômica, o volume de empregos formais era de 185 , em 2002, e 195, em 2003, e não parou de cair chegando a 44, em 2011. A retomada observada em 2012 e 2013 (112 e 122 postos de trabalho, respectivamente) não foi duradoura, pois nos anos 2015 e 2016 o número de empregados era de 91 (RAIS, 2002-2016).

\section{As explicações do fracasso e do desaparecimento do APL}

Já nas primeiras fases da fruticultura irrigada a literatura identificou falhas e limites. Levando em conta um período de mais de 10 anos de funcionamento do projeto, um alto especialista da fruticultura, entrevistado em Campos, afirmou que uma série de açóes em favor do programa, de 1999 a 2013, não se efetivaram por várias razóes: descontinuidade do programa, 
fortalecimento concorrencial da cadeia do petróleo e falta de mão-de-obra no campo.

A descontinuidade da política pública prejudicou o Projeto em todas as suas dimensóes. O governador que idealizou o programa saiu por causa da campanha presidencial; a vice-governadora que o sucedeu não deu continuação ao apoio estadual e a nova equipe desconhecia o setor e as açóes para a fruticultura; por fim, a vice-governadora foi eleita e não deu o mesmo impulso que no início do projeto, reduzindo as verbas direcionadas para o setor.

Com a rapidez, para não dizer a precipitação, da implementação do projeto ignorou-se os devidos cuidados necessários. Todos os entrevistados caracterizam o Projeto como fundamentalmente político, decidido sem a necessária consulta à sociedade que seria impactada. A planilha de custos da empresa que fez o estudo prévio era incompleta, com objetivos ambiciosos demais e cálculos e estimativas dos preços dos produtos, das produçóes e da produtividade sem bases robustas.

Havia também falhas institucionais que não facilitaram a condução do projeto ao longo do tempo. Nas agências de apoio e de assistência como, por exemplo, o Sebrae: o frequente turn-over das equipes locais impediu a transmissão das informaçôes sobre o programa e de conhecimento sobre as açôes já desenvolvidas anteriormente, o que causou uma perda de memória do órgão, uma descapitalização institucional. Ademais, o Sebrae se mobilizou para um outro programa (Produção Agroecológica Integrada Sustentável) dedicando menos atenção e meios para o Frutificar e, recentemente, segundo um entrevistado, para o desenvolvimento do Porto de Açu no município vizinho de São João da Barra.

As instituiçóes envolvidas, quaisquer que sejam os aspectos e as áreas de apoio e intervenções, foram numerosas ${ }^{7}$. Apesar desta concentração institucional, e mais provavelmente por causa dela, a devida coordenação entre os órgãos não foi assegurada e organizada. Esta falha fundamental também foi percebida já nos primeiros anos do projeto por La Rovere e Carvalho(2005), aspecto confirmado mais tarde por Meirelles Junior (2015).

A ausência de competências municipais no setor dificultou a sustentação da fruticultura irrigada pelas autoridades e pelos serviços locais. No município, as iniciativas em favor das atividades agrícolas sofreram da falta de articulação entre elas. As autoridades municipais limitaram o seu papel em acompanhar as iniciativas do ERJ e da Firjan seja por falta de experiência na gestão de projetos de desenvolvimento seja por falta de capacitação das secretarias locais. Esta postura municipal inexpressiva não facilitou a integração institucional das ações desenvolvidas em torno da fruticultura irrigada. 
Na prefeitura de Campos, não havia especialistas do setor e servidores de carreira envolvidos na agricultura irrigada e tampouco na fruticultura irrigada, mas sempre colaboradores sem concurso público que desconheciam esta área de atividade. A prefeitura durante muito tempo não tinha o cadastramento dos agricultores do município. Reforçando esta situação, alguns entrevistados da cidade de Campos lamentavam a longa falta de interesse da prefeitura para com os setores locais de atividades.

A falta de organização dos produtores para, por exemplo, mutualizar compras de insumos e vendas das produçóes evidentemente não ajudou o desempenho do projeto. A Emater-Rio tentou incentivar a criação de uma associação de produtores, sem sucesso. Assim, os fruticultores ficaram sem associação e sem cooperativa que incentivassem as ações coletivas do APL.

Não devemos ignorar um fato do contexto local: houve um movimento contínuo de migração para a indústria do petróleo na região, motivado pelas condiçôes de trabalho, consideradas bem mais brandas do que o cultivo no campo; os agricultores tinham, em média, uma idade avançada e os seus filhos não queriam continuar a atividade extremamente cansativa e pouco remuneradora, comprometendo o futuro das produçóes agrícolas - incluídas as das produções irrigadas.

O programa sofreu paradoxalmente de um conforto financeiro desestimulador: o enorme e crescente volume arrecadado dos royalties do petróleo pelo município a partir dos anos 1990 até a metade dos anos 2010. Essa abundância de rendas, segundo o imaginário local, podia sustentar e financiar novos e importantes investimentos e desestimulou o planejamento e outras formas mais estruturantes de desenvolvimento.

Finalmente, constatou-se que não existia, no município, uma governança mínima para se iniciar uma organização de um arranjo produtivo local. Alguns dos nossos entrevistados em Campos notavam que, para que um APL passe a existir, deveria preexistir na prática um verdadeiro arranjo produtivo; do mesmo modo, os mesmos duvidam das supostas vantagens de pertencer a um APL; por fim, comentam que a marca APL é mais uma palavra de moda que passou. Nem mesmo a Câmara Estadual de APLs mencionou o APL de fruticultura irrigada na lista de APLs do ERJ que acompanhava o convite da Secretaria da Casa Civil e Desenvolvimento para o 9o Encontro de APLs do ERJ, no dia 28 de novembro de 2017.

\section{O APL de cerâmica vermelha ${ }^{8}$}

A produção de cerâmica é uma atividade tradicional na região campista, e é uma importante atividade industrial ao lado da economia açucareira. 
Os principais produtos fabricados no município são os tijolos, as telhas, os blocos de vedação e os acabamentos. Esta atividade está ligada à construção civil, que influencia as variaçóes dos volumes produzidos tanto nas fases de crescimento da demanda quanto nas fases de crises das empreiteiras privadas e dos investimentos públicos. Em Campos, durante muito tempo houve concentração desta atividade, considerando o ERJ como um todo. Este fato associado a outros fatores favoráveis justificaram a seleção deste polo produtivo como APL. Já em 2001 existiam uma centena de empresas micro e pequenas formais neste setor que empregava 1.862 pessoas com carteira assinada. No mesmo ano, conforme Britto (2004) o volume de postos de trabalho formais e informais alcançou em torno de 5.000 e o pesquisador estimava os postos indiretos em torno de 25.000 .

Como foi observado em outras regióes do Brasil - por exemplo, no Vale dos Sinos no Rio Grande do Sul, onde a aglomeração das empresas de calçado se beneficiou de uma mão-de-obra que intercalava o seu emprego na indústria com trabalhos no campo segundo as estaçóes do ano - o setor ceramista de Campos, também se aproveitou disso, o que deu a ele, ao mesmo tempo, uma grande flexibilidade e um meio de conter a folha de pagamento nos custos de produção em períodos de baixa atividade. Com efeito, uma parte importante dos trabalhadores ceramistas trabalha também na cadeia açucareira nos campos de cana-de-açúcare nas usinas na estação do ano em que ela precisa de grande contingente de mão-de-obra. Como em qualquer atividade humana, o polo não é isento de contradiçôes, pois ao mesmo tempo em que os ceramistas aproveitam uma mão-de-obra flexível e barata, eles consideram que a desqualificação do pessoal era e é a principal dificuldade das empresas (COUTINHO, 2005-2006).

Em meados dos anos 2000, o polo cerâmico de Campos era considerado como o segundo maior produtor de tijolos do Brasil. A partir do município, saíam diariamente em torno de 400 caminhóes carregados de mercadorias para os mercados do Grande Rio, Sul Fluminense, Zona da Mata mineira e o estado do Espírito Santo (RAMOS, ALVES \& ALEXANDRE, 2006).

A matéria-prima é originária da exploração dos abundantes sedimentos argilosos no sudeste do município, perto da foz da Paraíba do Sul, que são beneficiados dos movimentos do mar e das inundaçóes. A maioria dos empresários são proprietários das jazidas, os demais arrendam áreas de exploração (ibidem p. 31). As fábricas, constituídas principalmente dos fornos e das áreas de secagem são quase que todas concentradas em uma mesma zona no sul da cidade de Campos, o que facilita as trocas de informaçóes e de opinióes entre os profissionais e concretiza e favorece certa solidariedade da classe. 
O sistema de produção já analisado em meados dos anos 2000 não mudou até recentemente': os fornos são de seis tipos, mas a principal diferença tecnológica entre os produtores pode ser caracterizada por uma minoria de ceramistas que usam processos de produção atualizados (fornos túneis, secadores e outras estruturas automatizadas) e a maioria que trabalha de forma rudimentar. A queima se faz, na maior parte dos casos, com lenha e óleos combustíveis; os resultados são assim descritos pelos especialistas: "pouca uniformidade das peças, geometria irregular e baixa resistência" (RAMOS, ALVES \& ALEXANDRE, 2006, p 32). As perdas pesam em termos de custo dos produtos comercializados.

Os ceramistas de Campos dispóem de um sindicato muito bem estruturado dos quais são membros mais de $80 \%$ dos fabricantes. O órgão de defesa e representação dos interesses da classe tem várias ligações formais e é bem conhecido e reconhecido pelas entidades públicas e agências de apoio (prefeitura, ERJ, Firjan, Sebrae, Universidades).

Após um longo período de expansão, o polo campista de cerâmica enfrentou nos últimos anos problemas endógenos e exógenos que, em conjunto, desanimaram o setor. Com efeito, e para resumir de forma simples a evolução da produção local, os estabelecimentos formais, que eram $106 \mathrm{em}$ 2002 aumentaram gradativamente até atingir 132 em 2012; de 2012 até 2016 o número diminui em 11 unidades (121) e em 2019, na visita de campo, o número era de 114. Do lado do emprego,em 2002, existiam 1.957 postos formais de trabalho, que cresceram ano após ano elevando o pico em 2013 para 3.096 trabalhadores; em seguida, aconteceu uma queda gradativa até 2016 com 2.299 empregos (RAIS, 2002-2016). O Sindicato, entrevistado em 2019, informou que, neste mesmo ano, o número tinha crescido- em torno de 3.000 - e, que havia mais ou menos 9.000 empregos indiretos, estes, em sua maioria, informais. Os empregados são oriundos, em sua maioria, do município (95\%), o que sugere a importância do setor para a formação da renda local e a movimentação do comércio campista. Em 2019, o sindicato das cerâmicas avalia que as empresas trabalham com $60 \%$ da capacidade de produção ocupada, esta taxa reflete a conjuntura pouco favorável.

$\mathrm{Na}$ verdade, são várias as dificuldades encontradas pelo polo de cerâmica. Do ponto de vista interno, um dos problemas do setor, não novo, mas duradouro e que pesa sobre o desenvolvimento das unidades de produção, é o custo do transporte. Sabe-se que atualmente a quase totalidade (95\%) da produção é vendida fora do município (Rio de Janeiro, Espírito Santo e Minas Gerais). O que significa que as localizaçôes dos compradores estão mais ou menos à $300 \mathrm{~km}$ de Campos. Segundo o sindicato, são 700 caminhóes que transportam regularmente os produtos que têm uma relação peso/unidade 
muito elevada. Este transporte é realizado por empresas terceirizadas (80\%) e $20 \%$ dos veículos pertencem aos fabricantes. Esta última taxa configura o nível mínimo necessário para que os ceramistas não dependam da disponibilidade de caminhóes de terceiros.

Outro problema do polo é a fonte de queima, cujas condições técnicas tradicionais (principalmente a lenha) explicam a baixa qualidade dos produtos, resultando na ausência de uniformidade e perdas importantes o que limita a competitividade do setor. Das 114 empresas em funcionamento, só 25 têm equipamento de gás natural, mas apenas uma empresa usa realmente esta fonte de energia, que favorece um melhor processo de queima e, por consequência, uma produção com qualidade superior. Trata-se de uma empresa de fabricação de telhas com alta qualidade cujo valor agregado é suficientemente elevado para poder compensar as despesas de gás. Apesar da Lei estadual 3.916 que previa a redução de $12 \%$ na alíquota do Imposto sobre Circulação de Mercadorias do gás utilizado na queima dos tijolos e de $20 \%$ no preço do produto, observamos que a quase totalidade dos fabricantes não aderiram a este dispositivo fiscal (RAMOS, ALVES \& ALEXANDRE, 2006). Segundo o Sindicato, no início da chegada do gás o preço era atrativo, mas pouco a pouco aumentou até que agora usar gás custa $40 \%$ a mais do que a lenha. Em São Paulo, o gás é mais barato do que em Campos, apesar de o gás ser proveniente da região fluminense.

Outro fato exógeno restringe as perspectivas de retomada do crescimento do polo. Um destino tradicional e importante das cerâmicas era a construção civil. Nesta área, os municípios do ERJ, compradores públicos habituais, têm enormes dificuldades financeiras e estão à beira da falência. Ao mesmo tempo em que surgiu a crise das finanças públicas, aconteceram algumas mudanças nas técnicas de construção que fez com que, por exemplo, o concreto substituísse os produtos tradicionais do polo.

Para continuar nesta série de dificuldades, existe em Campos um Laboratório que fazia análise, avaliação e certificação de produtos das empresas de cerâmica. Este Laboratório, que era credenciado, está fechado. Ele depende da Fundação de Apoio à Escola Técnica (FAETEC). A consequência disto é que, quando é necessário fazer análises, os produtos são mandados para Três Rios, município do ERJ, longe de Campos, na rota do Rio de Janeiro para Juiz de Fora (MG).

Um dos entrevistados relatou que houve no passado uma política de construção de casas populares planejada pelo governo estadual. A ideia inicial era que os produtores locais forneceriam os produtos, porém, na execução do projeto, quem ficou com a demanda foi uma grande empresa da construção 
civil que utilizou blocos "pré-moldados". Este fato é ilustrativo dos fatores que prejudicaram o desenvolvimento dos produtores locais.

Por fim, não menos importante, o modo extrativista da produção da matéria-prima, o uso da lenha para a queima, e o lançamento na atmosfera de resíduos tóxicos, são elementos da problemática ambiental que justificam legislações ambientais cada vez mais restritas (COUTINHO, 2005-2006) e influenciam negativamente o desenvolvimento do APL.

\section{As razões do fracasso do APL}

O reconhecimento oficial do APL se deu no ano de 2005, e as açóes de apoio foram iniciadas pouco tempo depois. O Sebrae de Campos concebeu as ações depois de fazer alguns estudos prévios e conversar com o Sindicato. Entretanto, a adesão das empresas foi baixa, somente 30 a 35 empresas sindicalizadas, isso representava mais ou menos um terço do total. As açóes diziam respeito às áreas de informação, de capacitação dos empresários, e de comercialização. $\mathrm{O}$ conjunto das intervenções se enquadrava em um programa de "treinamento das empresas". Um resultadodos apoios recebidos foi a criação da Central de Compras e Vendas. Mas, também neste caso, menos de uma dezena de empresas trabalham hoje com esta Central.

As açóes do Sebrae desapareceram gradativamente e finalmente acabaram entre o final de 2014 e o início de 2015 , por causa da crise da construção civil. Esta crise desmotivou muitos empresários. Todavia, os ceramistas precisam ainda de capacitação, mas o Sindicato vê uma barreira na relação com o Sebrae Campos, que não parece interessado na retomada das intervençóes de apoio.

Nos últimos anos, foi lançada a Rede Campos da Cerâmica (RCC), que substituiu em parte o APL. Mas, apenas 14 empresas estão vinculadas a esta Rede, por causa da crise da construção civil e da queda da produção, os empresários deixaram de ter interesse em participar de açóes coletivas.

A modesta retomada do crescimento a partir de 2016 não foi suficiente para compensar a queda da produção de cerâmica: nos últimos quatro anos, a queda acumulada foi de $30 \%$. Assim, uma taxa de crescimento de mais ou menos $6 \%$ por ano seria necessária para consolidar um ciclo de recuperação, o que não é o caso.

Um entrevistado, conhecedor do polo, observou que a dimensão local desta aglomeração é importante na medida em que os fabricantes atuam lado a lado em um perímetro bem delimitado, e que a matéria-prima fica na proximidade das unidades de produção o que poderia favorecer as açôes cooperativas entre os produtores. Mas, a ausência de o menor indício de divisão do 
trabalho entre os produtores não justifica denominar o polo como um arranjo produtivo. Como foi o caso da fruticultura irrigada, o ex-APL de cerâmica de Campos não foi mencionado na lista de APLs do ERJ por ocasião do 9o Encontro de APLs do ERJ, em 2017.

\section{A trajetória do APL Petróleo e Gás de Macaé10}

Desde os anos 1980, as atividades de prospecção e depois de exploração, cada vez mais intensificadas pela Petrobras, a decisão de escolher o porto de Macaé para abastecer as plataformas e os barcos nas jazidas offshore e de tornar o município sede terrestre das operaçóes da estatal, destacaram a enorme defasagem entre as exigências técnicas do pessoal atuando nestas atividades extrativas e nas indústrias afins e o medíocre nível de formação, capacitação e qualificação de milhares de pessoas, locais ou vindo de fora, procurando emprego e boa renda neste setor econômico. A chegada à cidade de empresas internacionais logo depois da abertura ao setor privado do regime legal da exploração do petróleo, e, por fim, a instalação de estabelecimentos fornecedores de máquinas e equipamentos especializados e de unidades prestadores

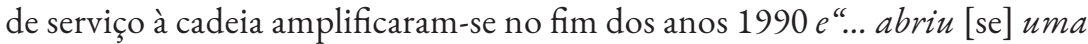
espécie de mercado muito proveitoso e lucrativo de oferta de apoio aos empregados e às empresas" (FAURÉ, 2005, p. 271).

Assim, no início dos anos 2000, surgiram em Macaé, capital do petróleo, uma infinidade de projetos e programas de apoio, dos mais modestos e pontuais até os mais estruturados e de longa duração cobrindo o mais largo espectro das necessidades de formação, capacitação, assistência técnica e gerencial não só das unidades envolvidas na cadeia do petróleo, como também dos estabelecimentos fora da cadeia, comércios e serviços, oficinas e lojas tradicionais ou recentemente instalados para participar da economia local e da prosperidade extrativa.

À Macaé foi outorgada a marca APL Petróleo e Gás $(P \& G)$ pelas instituiçóes federais e estaduais. Dentro das numerosas e diversificadas iniciativas de apoio e assistência, quatro foram fundamentais na concretização e na oferta dos serviços de ajuda resultantes da concessão do título de APL: Rumo à ISO 9000, Programa Qualidade Rio, Capacitação das Empresas Industriais, Capacitação de Fornecedores do P\&G. Fauré (2005) os estudou tendo em vista suas importâncias com relação ao conteúdo dos apoios em relação à cadeia, o tamanho dos públicos-alvo, e a antiguidade dos programas. Todos eles foram colocados em prática ao longo dos anos 2000. Eles contribuíram, sem dúvida nenhuma, ao aumento da qualificação do pessoal das empresas e até dos empresários. 
Mas, a eficiência dos apoios ficou longe do ideal. Com efeito, Fauré (2005), com base em um extenso questionário junto às 150 pequenas e médias empresas instaladas em Macaé, demonstrou que só $10 \%$ dos empresários entrevistados afirmaram terem sido beneficiados por programas de apoio, resultado fraco em função dos numerosos projetos atuando no município $^{11}$.

Quanto à oferta de apoios dos principais programas mencionados acima, pôde-se perceber a superposição destes e falta de articulação entre as respectivas atividades. O sistema geral de apoio em Macaé careceu de governança, que era indispensável devido à oferta de apoio diversificada e oferecida por várias instituiçốes. De forma geral, os empresários que participaram dos programas de apoio, principalmente aqueles que apenas presenciaram palestras e conferências pontuais, reconheceram pouco mérito nos programas, e efetividade no desempenho dos seus negócios, segundo os entrevistados.

No mesmo período, houve em Macaé grandes esforços também para multiplicar o número de escolas, de colégios e de faculdades em face da demanda crescente por educação. O que contribuiu para o aumento do capital humano no município e região.

\section{As razões do fracasso do APL}

Como o Brasil, Macaé sofreu a partir de 2014, como visto na primeira seção, de uma queda espetacular das atividades econômicas, conduzindo o país à mais importante recessão da sua história moderna e com consequências dramáticas em termos de desemprego e de perda de renda das famílias. Mas, a crise apresentou em Macaé características peculiares. Em valores correntes, o PIB municipal perdeu 16\% de 2014 para 2015 e 19\% de 2015 para 2016. O setor mais afetado foi a indústria - incluídas as atividades extrativas vinculadas à exploração do $P \& G$ - cuja queda foi de $43 \%$ entre 2014 e 2016. A fraca retomada depois de 2016 não compensou as perdas anteriores. Enquanto, o PIB per capita macaense tinha obtido o seu auge em 2014 (coeficiente multiplicador de 2,59 em relação ao ano de 2002) o mesmo indicador caiu drasticamente ao coeficiente de 2,04 em 2016 por causa do importante crescimento demográfico que não parou nos anos críticos $(+71 \%$ de 2002 a 2016). O número de estabelecimentos formais, que aumentava cada ano desde 2002, diminuiu em 159 unidades de 2014 para 2016. O emprego formal, que praticamente tinha triplicado de 2002 a 2014, foi reduzido em 35.000 postos entre 2014 e 2016. As atividades extrativas, as mais impactadas, perderam $26 \%$ de postos de trabalho entre estes dois anos (HASENCLEVER \& FAURÉ, 2019). 
Além dos efeitos conjunturais e macroeconômicos, o fato de o município ser especializado na economia do petróleo contribuiu para provocar esta enorme baixa nas atividades locais: a queda de mais ou menos dois terços do preço do barril de petróleo no mercado internacional; os problemas financeiros e judiciários da Petrobras que reduziram a sua capacidade de investimentos; a diminuição gradativa da produção das jazidas maduras por terem sido exploradas há mais de 20 ou 30 anos $^{12}$. O orçamento da prefeitura sofreu uma queda considerável das suas receitas, limitando assim as suas margens de manobra para investir e ajudar financeiramente programas e projetos. Com efeito, os royalties e participaçóes especiais que atingiram em torno de 57\% das receitas orçamentais em 2006 diminuíram em 46\% entre 2014 e 2016, representando apenas $15 \%$ do orçamento municipal neste último ano (KEHL \& WAGNER, 2019) ${ }^{13}$.

Em 2015, para enfrentar a crise financeira, a prefeitura demitiu vários celetistas, cancelou centenas de cargos comissionados, reduziu a folha de pagamento dos demais funcionários, reduziu drasticamente o número de secretarias municipais e de autarquias, diminuiu fortemente os meios de funcionamento cotidiano da "máquina” pública (veículos, dentre outros), e o prefeito e vice-prefeito, assim como os secretários que se mantiveram, tiveram suas remuneraçóes reduzidas, para dar o exemplo da necessária e nova austeridade (GARABINI, 2015).

$\mathrm{O}$ conjunto destes infelizes eventos gerou impactos sobre os programas de apoio oferecidos no APL P\&G de Macaé, que já não tinham a mesma densidade e a mesma força que no início dos anos 2000. De fato, foi possível constatar que em 2016 os principais programas de apoio apresentados nos desenvolvimentos anteriores (ISO 9000, Qualidade Rio) desapareceram e os programas voltados à capacitação continuaram de forma mais pontual, ou seja, respondendo apenas às demandas das empresas.

Como foi o caso dos dois APLs de Campos, o termo APL desapareceu progressivamente do vocabulário dos responsáveis das agências e balcôes locais de desenvolvimento. Outra expressão surgiu para designar o aglomerado de empresas em torno da cadeia do $P \& G$ e as ações empregadas em favor delas. Pouco a pouco se falou de Rede Petro-BC, apesar desta entidade existir desde os anos 2000, ganhou força a partir do enfraquecimento das açóes voltadas ao APL. A Rede se apresenta como "uma associação de empresas certificadas segundo normas reconhecidas nacional e internacionalmente pelo mercado de petróleo, gás e energia" (Rede Petro Rio, 2019, p. x). A sua missão é fomentar negócios e dar visibilidade às empresas associadas. O espaço utilizado é cedido pela Firjan e as questôes financeiras são geridas pela Associação Industrial e Comercial de Macaé. 


\section{DISCUSSÃO}

O desaparecimento, e até a extinção, dos três APLs estudados não é específico da região norte-fluminense. A Política de APLs, e os programas surgidos a partir de 2004, praticamente se extinguiram em torno de 2014 através de um refluxo geral causado por um conjunto de fatores adversos: crise financeira, déficit fiscal dos entes da federação, Núcleos estaduais de APLs menos ativos, problemas de governança dos dispositivos locais e fraco protagonismo dos atores, resultados pouco satisfatórios, avaliaçôes objetivas raras, novas preocupaçôes e novos rumos da economia nacional. Resultados que ilustram a falta de um projeto maior de desenvolvimento, como o apontado por Carleial (2014) e Bacelar (2013) na introdução, que permitisse o enfrentamento concatenado de todos estes fatores adversos.

A evolução negativa dos três APLs analisada anteriormente, produto das dificuldades e de limites internos e de fatores externos, do afastamento dos órgãos de apoio e da decadência das políticas e dos programas, teve forte influência também do baixo dinamismo dos contextos municipais apresentado na primeira seção. Os municípios demonstraram poucos avanços em termo de crescimento e a fortiori ainda menos em termo desenvolvimento econômico e humano.

Assim, é possível observar que os APLs estudados aqui não aproveitaram os efeitos positivos da longa primeira fase de expansão das economias municipais para estabelecer um projeto de mudanças estruturais e melhoria do bem-estar das populações. A falta de integração dos projetos nos tecidos locais de atividades, ligações a montante e a jusante e articulaçóes setoriais débeis, a ausência de governança e o ritmo inadequado dos projetos de infraestrutura podem ser, em parte, as causas da falha da Política de APLs, conforme discutido nas subseçóes a seguir.

As potencialidades não exploradas: os polos sem a marca APL

Pode-se afirmar, portanto, que os APLs estudados não tiraram proveito do contexto econômico favorável até os anos 2012/2014. Além disso, os municípios de Campos e Macaé perderam provavelmente a oportunidade de adensar os tecidos locais, apostando sobre outras concentrações de atividades, outras especialidades que poderiam provocar certa emulação holística em cada cidade e estimular os APLs investigados. Apesar dos setores de atividades serem diferentes entre os APLs e os outros polos, as trocas e ligaçốes entre eles teriam sido possíveis, mas não foram encorajadas.

Existe em Campos um polo moveleiro cujo potencial de crescimento foi identificado já no início dos anos 2000 por La Rovere e Carvalho (2005). 
Atualmente, 200 estabelecimentos atuam neste setor e um pouco mais de 40 estão associados ao sindicato da classe. Dentre os associados, somente cinco ou seis fabricantes interagem regularmente, por exemplo, compartilhando insumos. A principal produção é a fabricação de móveis escolares (sobretudo mesas e cadeiras). E um setor impulsionado pela demanda direcionada às unidades e não pela oferta de produtos; com efeito, os fabricantes acompanham os editais municipais da região e atendem às encomendas. O processo de fabricação não dá espaço para a divisão do trabalho e a especialização das fases: no caso de grandes licitações e editais os fabricantes produzem juntos, mas cada um produz uma parte equivalente da produção final. Algumas operações de fabricação são mais intensivas em mão-de-obra, pois essa é considerada mais eficiente do que equipamentos técnicos e máquinas (caso, por exemplo, da solda). Representantes do polo não viram benefício em solicitar a marca APL. Estas opiniôes, na verdade legítimas, sobretudo conhecendo os problemas dos APLs, não impede de pensar que, no passado, um plano de apoio poderia, além de açôes específicas (alterar a lógica do sistema produtivo impulsionado exclusivamente pela demanda, diversificar a produção em termo de produtos, de matéria prima, de design, integrar mais tecnologias, estimular a cooperação interna), suscitar ou reforçar algumas relações com outros setores locais de atividade. Difícil imaginar que nenhuma sinergia fosse possível.

O município de Campos se distingue pela presença de um denso conjunto de estabelecimentos de ensino superior, de centros de pesquisa e de laboratórios com grande qualidade, e cuja fama abrange toda região. Até agora, todavia, se trata mais de um acúmulo de instituições do que um verdadeiro polo que necessitaria de uma governança geral. Esta situação não potencializa todos os benefícios coletivos e sociais que o setor poderia ganhar com açôes coletivas

Por fim, a cidade de Campos acolhe muitas entidades que têm a ver com a área da saúde: universidades e faculdades, públicas e particulares, laboratórios de análise, hospitais, clínicas, centros de saúde, oficinas de enfermagem, ambulâncias e profissionais de saúde. Será que todas as oportunidades para ampliar as relaçóes e facilitar ligaçóes com outros setores foram aproveitadas? A perspectiva de desenvolver no município um tipo de "turismo de saúde", já identificada e relatada pelos entrevistados, conseguirá passar da ideia à realização?

Em Macaé, a pesca é um setor muito antigo e tradicional do município ao lado da agropecuária. Ela foi praticamente abandonada com a presença e as normas da Petrobras que limitou as áreas de retirada dos recursos da pesca. Mas, um acordo de bom entendimento aconteceu entre as duas partes. 
A prefeitura, já nos anos 2000, ajudou centenas de pescadores para organizá-los, melhorar as instalações, apoiar um sistema de assistência e de cursos profissionais. Mais recentemente, a prefeitura favoreceu a construção de um mercado de peixe, grande e moderno. A pesca constitui assim um polo real e dinâmico de atividade sem ter se beneficiado da marca de APL.

\section{O desenvolvimento possível no futuro próximo}

A partir das experiências de APLs relatadas anteriormente e das noçóes diferenciadas de crescimento e de desenvolvimento detalhadas nas seçôes anteriores é permitido esboçar algumas perspectivas de sucesso nas três economias municipais. Ė evidente que alguns pré-requisitos serão necessários para passar de um esquema idealizado para a realidade concreta. Uma das condiçóes será o retorno a um contexto geral favorável às decisóes, ações e projetos, ou seja, a retomada do crescimento nas escalas nacional, estadual e local. Difícil imaginar que os programas de ação locais possam funcionar e provocar efeitos positivos de forma isolada sem relaçóes às demais atividades econômicas como infelizmente até agora foi o caso de muitos APLs. Para ultrapassar a simples etapa de crescimento em direção a uma fase sustentável de desenvolvimento os programas de ação de verão alcançar certa dimensão, certa escala e ter um ciclo duradouro de vida e uma maior governança entre as várias escalas local, nacional e internacional.

Programas pequenos ou incipientes em Campos: o desafio de escalonar esses programas

Em Campos, é obvio que as atividades que foram objetos de APLs e os outros polos não contemplados com a Política de APLs descritos acima continuarão a animar as atividades econômicas do município e precisarão de atenção, de assistência e de apoio para não estagnar ou desaparecer. Existem atualmente vários programas da prefeitura para dinamizar o tecido econômico local, propor ações de inclusão social, atender a demandas da população. Entre eles, destaca-se o Fundo de Desenvolvimento de Campos (Fundecam) cuja atuação foi relançada depois de um período de dificuldades. Por iniciativa própria, e com a ajuda de programas como o Sistema de Gestão de Consultoria Tecnológica (Sebraetec), da Empresa Brasileira de Pesquisa e Inovação Industrial (Embrapii) e sem esquecer o papel da Companhia de Desenvolvimento Municipal de Campos (Codemca), as linhas de atuação do Fundo incidem nas áreas da economia solidária, da agricultura familiar, da fruticultura, da cana-de-açúcar e do empreendedorismo. Desde 2017, cerca de quatro mil pessoas se tornaram microempreendedores através da Casa do 
empreendedor funcionando na cidade ${ }^{14}$. Uma linha de financiamento do Fundecam sustenta assim vários tipos de apoio.

$\dot{E}$ evidente que estas iniciativas são totalmente legítimas e necessárias. Entretanto, elas não podem rivalizar com o alcance de políticas públicas de desenvolvimento e estão sendo implementadas em um contexto de queda das transferências governamentais e de royalties e de dificuldades nas contas públicas municipais. Portanto,para evitar que elas sejam apenas de cunho assistencialista ou paliativas a pauta de açóes do Fundecam deverá reforçar-se, atingir um público considerável, aumentar os recursos financeiros e fazer com que os pequenos empresários cresçam para sair da condição que os aproxima da informalidade.

Em Campos, o ecossistema de inovação está em processo de estruturação. Ele visa uma melhor articulação entre as instituições de ensino superior e de pesquisa, os serviços municipais e o setor produtivo para facilitar o surgimento de novas empresas - diferentes das lojas dos comerciantes e oficinas dos artesãos tradicionais - e novos produtos a partir do desenvolvimento científico e tecnológico da região. Várias entidades participam: a prefeitura, o Sebrae, o Embrapii, o Instituto Federal Fluminense (IFF), dentre outras. Um dos desafios desta iniciativa será aproximar o meio universitário do meio empresarial, pois geralmente as relações entre eles são bastante problemáticas. Se as dificuldades da transferência de conhecimento das universidades para as empresas são uma regra no mundo todo, o ecossistema campista de inovação poderá contribuir com a criação de um sistema produtivo moderno que integra cada vez mais conhecimento e tecnologia às atividades produtivas. Mas, para alcançar o sucesso, os obstáculos não são pequenos.

\section{Os programas estruturantes em Macaé}

Depois de ter enfrentado, além do contexto geral recessivo, uma profunda crise do setor petrolífero, Macaé está caminhando nos dias de hoje para uma nova fase de crescimento, que, na visão de alguns entrevistados na cidade, não será tão alta e triunfal quanto no passado. Este novo ciclo é baseado em projetos de grande amplitude e é resumido pelos dirigentes e gestores pelas expressóes 'capital do gás', ou 'cidade da energia e do conhecimento'.

O principal destes projetos é o Parque Térmico do Sudeste, que envolve a Agência Nacional de Energia Elétrica e outros atores e que é considerado como essencial para o equilíbrio térmico do país. Concentrado em Macaé, o parque envolve Campos e São João da Barra. O gás é um recurso bastante abundante na região, que ao longo do tempo foi perdido por ter sido queimado offshore. A Unidade de Processamento de Gás Natural 
está sendo licenciada no momento da presente pesquisa. Hoje, já existem cinco termoelétricas no município e a esperança é que novas rotas de gás desembarquem no território de Macaé para atrair novas plantas térmicas. O licenciamento de mais duas Unidades Termoelétricas (UTEs) estão em curso para atingir sete UTEs, no total, em Macaé. Além do duto que transporta o gás do terminal macaense de Cabiúnas para as térmicas o projeto de construção de um porto terrestre, o chamado Terminal Portuário de Itajaí, terá o papel de sustentar estes importantes empreendimentos na área do gás. Em torno destes, é esperada a instalação de empresas prestadoras de serviço. Esta perspectiva é uma possibilidade de compor uma base de manutenção industrial e da cidade tornar-se uma plataforma de conhecimento. É também uma forma de evitar que Campos e São João da Barra se tornem uma solução para a localização das novas empresas, ampliando a centralidade de Macaé na região norte-fluminense.

Estes programas são complementados pela implementação, em curso, do Complexo Logístico e Industrial de Macaé ligado por rotas de transporte novas ao Parque de Tubos; assim, será constituído um conjunto de plantas atuando nas operações onshore da indústria de óleo e gás no município. Além disso, a Petrobras, apesar de uma importante dívida, anunciou, no final de 2017, investimentos da ordem de 19 bilhões de dólares para a Bacia de Campos $(G 1,2017)$ incluindo obras de recuperação e revitalização de poços maduros, a reforma de 39 plataformas e a instalação de quatro novas plataformas e seis novos blocos exploratórios.

Assim, e para nos limitarmos a esses projetos, alguns em andamento, outros planejados, podemos perceber a magnitude dos efeitos possíveis sobre a economia local com a contratação de milhares de trabalhadores e a chegada de novas plantas industriais. Se o conjunto destes projetos for colocado em prática haverá a oportunidade de forte crescimento e até de desenvolvimento de vários segmentos da sociedade municipal que se beneficiariam de mudanças positivas frutos do novo período de expansão.

Mas, para atingir a este desejável patamar o município e a prefeitura deverão superar algumas dificuldades e atender às necessidades provocadas pelo tamanho e pelo ritmo do crescimento. $\mathrm{Na}$ área do petróleo, apesar de haver um bom entendimento entre a Petrobras e a prefeitura, se as instalações são locais, a iniciativa e as decisões dos projetos são tomadas longe de Macaé, na sede da estatal. O papel municipal será o de acompanhar as intençôes da Petrobras e das outras grandes empresas do setor para oferecer as infraestruturas sociais, educativas e sanitárias necessárias. Também, como foi o caso no período de prosperidade até 2014, haverá uma enorme necessidade de capacitação dos trabalhadores, além das formações e qualificações 
organizadas pelas grandes empresas. A prefeitura está ativa para preparar e agilizar a realização dos projetos, tendo criado no dia de 23 maio de 2017 uma Comissão de Licenciamento Municipal com a participação de sete secretarias. O objetivo é facilitar as licenças necessárias dos projetos considerados estruturantes e ao mesmo tempo planejar os investimentos municipais necessários, buscando uma harmonia entre crescimento e desenvolvimento.

\section{CONCLUSÃO}

A primeira seção deste artigo indica que as economias de Campos e Macaé evoluíram inicialmente em um quadro geral de forte crescimento e que a queda dos PIBs, no fim dos períodos, coincidiu com - e provavelmente influenciaram - a redução dos interesses dos beneficiários em participar dos projetos e das agências de fomento para estimular os APLs que foram perdendo a sua força como Política.

As trajetórias e os resultados apresentados na segunda seção do estudo mostram como a relação entre os APLs e o desenvolvimento local é totalmente incerta: as ações desdobradas e colocadas em práticas em cada APL não foram suficientemente numerosas, pertinentes, sólidas e contínuas para gerar efeitos positivos ao longo dos anos e dinamizar com sustentabilidade o conjunto das unidades de produção das aglomerações contempladas com a Política de APLs nos três setores. Constatou-se descontinuidade das políticas públicas, inclusive do Sebrae, a falta de capacidade estatal das prefeituras em várias áreas e até mesmo o uso político-eleitoral e ineficiente dos APLs.

Mas, esta constatação negativa sobre o resultado dos estudos de caso municipais e dos três APLs não esgota, na visão dos autores, a problemática do crescimento e do desenvolvimento. A presente pesquisa tentou mostrar que o crescimento - e às vezes o desenvolvimento econômico - existe ou pode existir fora ou apesar da política e dos programas de APLs, como foi o caso da cerâmica vermelha em Campos e do P\&G em Macaé. Há uma vida econômica possível, e possivelmente bem-sucedida, sem a marca e os apoios da Política de APLs. Isso sugere que os planos de ação e os projetos de desenvolvimento local não devem ser pensados como exclusivamente alavancados a partir do curso da economia local. Mas a busca do crescimento e, sobretudo do desenvolvimento econômico e humano é uma questão de opção política, no sentido nobre do termo, pois se trata de construção de uma estratégia de desenvolvimento não só local, mas regional e nacional.

Porém, se existem fatores gerais conhecidos para impulsionar as atividades produtivas, não existem receitas prévias universais e intertemporais para o crescimento e ainda menos para o desenvolvimento econômico e humano, 
resultado de vontade estratégica, de mobilização de recursos humanos e materiais e de oportunidades aproveitadas ou não. Cada situação é peculiar, pois são vários fatores que condicionam a gestão, a governança, o futuro de cada aglomeração de atividade.

Existem obviamente certas constantes como: a reação aos projetos concebidos e colocados em prática de cima para baixo, a importância da governança dos projetos e programas, a articulação entre as ações, a atenção sobre o conhecimento local, a participação de todos os atores, o engajamento, a responsabilidade dos gestores, a prestação de contas, a competência, o acompanhamento contínuo das atividades, a adaptação e a flexibilidade dos projetos para superar as dificuldades encontradas. Enfim, o que parece cada vez mais necessário é a articulação interinstitucional e inter-escalas, que daria uma capacidade de governança maior, e recorrer às avaliações externas e rigorosas, capazes de apontar as melhorias necessárias na Política de APLs, sem esquecer a importância de o protagonismo municipal apoiar e reforçar as economias locais não contempladas pela Política.

\footnotetext{
Notas

1 Política capitaneada pelo Ministério do Desenvolvimento, Indústria e Comércio Exterior,envolveu vários organismos federais, como o Banco Nacional de Desenvolvimento Econômico e Social (que criou com a presidência da República uma área que trata desse tipo de política), o Banco do Brasil (no seu programa de Desenvolvimento Regional Sustentável), o Ministério da Ciência e Tecnologia (dada a importância da promoção da inovação nesse tipo de política pública), entre outros. O Sebrae também se juntou a esse esforço dada a predominância das micro e pequenas empresas nos APLs.

${ }^{2}$ Não abordaremos neste texto a política de APLs no contexto do desenvolvimento brasileiro nem a questão das avaliações desta política assuntos já tratados por Hasenclever e Fauré(2019).

${ }^{3}$ As publicações e um documento de metodologia estão disponíveis no site da Firjan (https://www.firjan. com.br/publicacoes/). No que diz respeito ao IFGF nos limitaremos aqui a apresentar o índice geral sem desagregar os dados por grupos de indicadores.

${ }^{4}$ Para um aprofundamento deste tema ver Silva et al. (2020).

${ }^{5}$ Este tipo de significado ocorre quando os programas ou a política a respeito perdem fôlego ou desaparecem e, sobretudo na medida em que raramente os programas APLs abrangem o conjunto das unidades do mesmo setor e da mesma localidade e, muitas vezes, uma parte mais ou menos importante de produtores não participava das ações de apoio - situações bem frequentes em todo o Brasil na vigência da Política.

${ }^{6}$ Além dos estudos mencionados nesta seção as informações utilizadas provêm de várias entrevistas realizadas em Campos dos Goytacazes e de uma antiga visita ao polo de fruticultura por um dos autores da presente análise.

7 UFV, Emater-Rio, Universidade Federal Rural do Rio de Janeiro, Universidade Estadual do Norte Fluminense Darcy Ribeiro (UENF), Fundação Norte Fluminense de Desenvolvimento Regional, Firjan, Governo do ERJ, Serviço Nacional de Aprendizagem Industrial (Senai), o Serviço Brasileiro de Apoio às Micro e Pequenas Empresas (Sebrae/RJ), Serviço Social da Indústria (Sesi), Pesagro-Rio, Fundação Estadual do Norte Fluminense, Serviço Nacional de Aprendizagem Rural (Senar), BNDES, Empresa Brasileira de Pesquisa Agropecuária, e Secretaria de Agricultura e Pecuária.

${ }^{8}$ Além dos documentos mencionados ao longo desta seção os autores ministraram várias entrevistas em Campos.
} 


\footnotetext{
${ }^{9}$ As informações técnicas a seguir se baseiam em Ramos, Alves e Alexandre (2006). Algumas entrevistas feitas pelos autores do presente documento confirmaram estes pontos.

${ }^{10}$ Além dos documentos mencionados a seguir, as visitas de campo, várias entrevistas e a exploração dos jornais locais foram importantes fontes de informação.

${ }^{11}$ Fauré (2005, p. 285-292) detalha algumas causas desta situação insatisfatória tanto do lado empresarial quanto do lado do funcionamento das entidades de apoio.

${ }^{12} \mathrm{O}$ declínio produtivo da Bacia de Campos pode ser resumido assim: presentemente ela contribui apenas à 44\% da produção total offshore contra 85\% no pico dos anos anteriores e já a Bacia de Santos é responsável por 50\% da produção por ter campos mais novos e localizados no pré-sal.

${ }^{13}$ Não abordamos, nesta análise, os efeitos da crise sobre as demais atividades econômicas do município onde muitas lojas e vários serviços fecharam no período selecionado aqui.

${ }^{14}$ As formações de um polo de programadores em parceria com a UCAM e de uma Liga gastronômica são, dentre outros, exemplos de iniciativas municipais.
}

\section{Agradecimentos}

Agradecemos ao Conselho Nacional de Desenvolvimento Científico e Tecnológico pelos recursos de custeio para o Projeto Os limites e as contradições da política de arranjos produtivos locais: estudo de caso da região norte fluminense, Campos dos Goytacazes, São João da Barra, Macaé.

\section{Referências}

ARAÚJO, T. B. Desenvolvimento Regional Brasileiro e Políticas Públicas no Governo Lula. In: SADER, E. (Org.) 10 Anos de Governos Pós-neoliberais: Lula e Dilma. São Paulo: Editorial Boitempo/Flacso, p. 143160, 2013.

BRITTO, J. Arranjos Produtivos Locais. Perfil das Concentrações de Atividades Econômicas no Estado do Rio de Janeiro. Rio de Janeiro: UFF, FUNCEX, UFRJ/IE, Sebrae RJ, 2004.

CARLEIAL, L. O Desenvolvimento Regional Brasileiro Ainda em Questão. Revista Política e Planejamento Regional (PPR), v. I, n. 1, p.1-21, jan./jun. 2014.

COUTINHO, J. C. S. Indústria Cerâmica de Campos: um retrato em preto e branco. 2005-2006. Dissertação (Mestrado em Planejamento Regional e Gestão de Cidades), Universidade Candido Mendes, Campos de Goytacazes.

FAURÉ, Y.-A. Macaé: internalizar as oportunidades do petróleo e diversificar a economia municipal. In: FAURÉ, Y.-A.; HASENCLEVER, L. (Orgs) O Desenvolvimento Local no Estado do Rio de Janeiro. Estudos avançados nas realidades municipais. Rio de Janeiro, E-Papers, 2005, p. 215-322.

FAURÉ, Y.-A.; HASENCLEVER, L. (Orgs) Caleidoscópio do Desenvolvimento Local no Brasil. Diversidade das abordagens e das experiências. Rio de Janeiro, E-Papers, 2007.

$\mathrm{G} 1$ - Macaé. Petrobras divulga investimento de US $\$ 18,9$ bilhões na Bacia de Campos para os próximos 5 anos. 21/12/2017, 19h27. Disponível em: $<>$. https://glo.bo/2YBhOGX. Acesso em: 15 out. 2019.

GARABINI, T. Dr. Aluízio anuncia quais serão as medidas para enfrentar crise financeira nacional. Macaé: Diário da Costa do Sol, 17 a 19 de janeiro de 2015.

HASENCLEVER, L.; FAURÉ, Y.-A. Limites dos Arranjos Produtivos Locais: Macaé no cenário de reconfiguração da cadeia de petróleo e gás. In: ABREU e SILVA, S. R. de; CARVALHO, M. R. de (Orgs) Macaé do Caos ao Conhecimento. Prefeitura Municipal de Macaé, 2019, p. 475-501.

KEHL, L. R. S.; WAGNER، G. P. A Evolução das Arrecadações de Royalties e Participações Espaciais e seus Impactos 
Orçamentários de Macaé no período 2013 a 2018. In: ABREU e SILVA, S. R. de; CARVALHO, M. R. de (Orgs). Macaé do Caos ao Conhecimento. Macaé: Prefeitura Municipal de Macaé, 2019، p. 250-261.

LA ROVERE, R. L.; CARVALHO, R. L. Campos de Goytacazes: os desafios da transformação de um epicentro regional. In: FAURÉ, Y.-A.; HASENCLEVER, L. (Orgs). O Desenvolvimento Local no Estado do Rio de Janeiro. Estudos avançados nas realidades municipais, p. 73-138, 2005.

\section{LASTRES, H. M. M.; CASSIOLATO, J.}

E; CAMPOS, R. Arranjos e Sistemas Produtivos Locais: vantagem do enfoque. In: LASTRES, H. M. M.; CASSIOLATO, J. E (Orgs). Estratégias para o desenvolvimento: um enfoque sobre arranjos produtivoslocais do Norte, Nordeste e Centro-Oeste brasileiros. Rio de Janeiro: E-Papers, 2006, pp. 13-28.

MEIRELLES JUNIOR, J. C. Avaliação do Programa Frutificar: uma política pública do estado do Rio de Janeiro aplicada no município de Campos dos Goytacazes. 2015. Tese (Doutorado em Ciência, Tecnologia e Inovação em Agropecuária) - PróReitoria de Pesquisa e Pós-Graduação, Universidade Federal Rural do Rio de Janeiro, Seropédica.

PERROUX, F. Dictionnaire économique et social. Paris, Hatier, 1990.

REDE PETRO RIO. Associação das Empresas Fornecedoras do Setor de Petróleo, Gás e Energia do Rio de Janeiro. Disponível em: <http://redepetrorio.com. br/>. Acesso em: out. 2019.
RELAÇÃO ANUAL DE INFORMAÇÕES SOCIAIS - RAIS: competência $2002-$ 2016. Brasil. Ministério da Economia. Secretaria Especial de Previdência e Trabalho. Brasília. Disponível em: <http:// bi.mte.gov.br/bgcaged/rais.php >. Acesso em: out. 2019.

RAMOS, I. S.; ALVES, M. G.; ALEXANDRE, J. Diagnóstico do Polo Cerâmico de Campos dos Goytacazes - RJ. Cerâmica Industrial, v. 11, n. 1, p. 28-32, jan.-fev. 2006.

SADER, E. (Org.). 10 Anos de Governos Pós-Neoliberais: Lula e Dilma. São Paulo: Editorial Boitempo/Flacso, 2013.

SILVA, F. F.; HASENCLEVER, L.;

FAURE, Y-A; MATIAS, I.O. Evolução do desenvolvimento humano dos municípios do Rio de Janeiroentre 2005 e 2016. R. Tecnol. Soc., Curitiba, v. 16, n. 39, p. 76-93, jan/mar. 2020.

SCHMIDT FILHO, R.; DE PAULA, N. M. Incentivos à formação de APLs no Brasil: A atual distribuição espacial das iniciativas e evidências de uma falsa política industrial. Informe GEPEC, v. 12, n. 1, p. 1-17, jan./jun. 2008.

SCHUMPETER, J. A. Teoria do Desenvolvimento Econômico. São Paulo: Editora Nova Cultural Ltda, 1997. TRIBUNAL DE CONTAS DO ESTADO DO RIO DE JANEIRO - TCE/RJ: competência 2002 - 2016. Rio de Janeiro. Disponível em: 〈https://www.tce.rj.gov.br/>. Acesso em: out. 2019 .

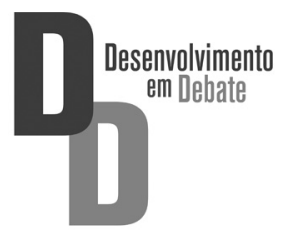





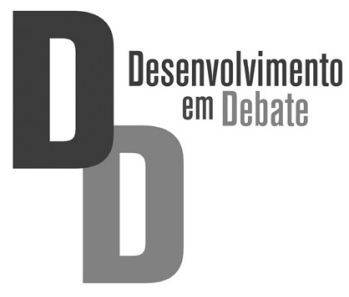

\section{POLITTICA EDITORIAL}

A equipe editorial da revista Desenvolvimento em Debate se compromete a manter elevada conduta ética durante todo o processo em relação à publicação e seus colaboradores; rigor com a qualidade dos artigos científicos a serem publicados; selecionar revisores capacitados e ecléticos com educação ética e respeito profissional aos autores e ser imparcial nos processos decisórios, procurando fazer críticas sempre construtivas e profissionais. Para tal fim, a revista adota o código de conduta do Conselho Nacional de Desenvolvimento Científico e Tecnológico (http://www.cnpq.br/web/guest/diretrizes).

A revista publica artigos originais de pesquisa, ensaios e resenhas relacionados com a temática do desenvolvimento socioeconômico. Ênfase é dada a trabalhos que analizam o papel do Estado e das instituiçóes no desenvolvimento, políticas públicas setoriais e estratégias de desenvolvimento, o papel da geopolítica na dinâmica econômica e sustentabilidade ambiental, como também a pesquisas acerca de casos nacionais ou em perspectiva comparada, sobretudo de países da América Latina.

Os textos submetidos para publicação podem ser em português, espanhol ou inglês e devem ser inéditos. Ocasionalmente, por seu mérito acadêmico, a revista publica traduzóes de artigos originais em linguas que não sejam o português.

Pelo menos um dos autores deve ter a titulação mínima de mestre.

A revista adota o processo de avaliação por pareceristas anônimos. Os artigos passam por um processo de avaliação com três etapas. Na primeira, de caráter formal, avalia se o texto respeita as normas editoriais. $\mathrm{Na}$ segunda, decide se o artigo se adequa ou não ao escopo da Desenvolvimento em Debate. Em caso de ser negativo, comunica aos autores o motivo da rejeição. Em caso de ser positivo, o artigo é enviado a pareceristas externos. A publicação está condicionada à aprovação por parte de dois avaliadores externos à revista. 
O corpo editorial pode aceitar artigos para publicação, com ou sem recomendação de alteraçôes. Nõ caso de serem necesárias alterações, a versão final do artigo deve ser enviada no prazo de um mês posterior ao envio da avaliação dos pareceristas externos.

\section{NORMAS PARA A SUBMISSÃO DE ARTIGOS}

- Os artigos devem ser submetidos pelo correio eletrônico da revista: revdesenvolvimentoemdebate@gmail.com.

- Os artigos submetidos devem ter entre 7,000 e 12,000 palavras (incluindo as notas de fim, resumos, bibliografia e legendas), em fonte Times New Roman, tamanho 12, com espaço 1,5 e parágrafo justificado.

- Os manuscritos devem incluir um resumo em português e em inglês, explicitando objetivos do artigo, metodologia epregado e as principais conclusóes. O resumo deve ter entre 100 e 150 palavras e deve ser acompanhado de entre 3 a 5 palavras-chave.

- Devem ser submetidos no mesmo processo dois arquivos. Um contendo os dados dos autores e outro com o manuscrito sem identificação de modo de evitar qualquer informação que revele a autoria do artigo.

- As notas de fim deverão ser evitadas ao máximo e, quando existirem, restringirem-se a conteúdo e estarem enumeradas automaticamente em algarismos arábicos em ordem crescente e listadas no final do texto.

- As citações diretas com mais de três linhas devem estar destacadas do texto, recuadas $4 \mathrm{~cm}$ à esquerda e com espaçamento simples entre linhas. O texto deverá ser digitado em Word For Windows e não deverá ter numeração de páginas.

- As figuras devem incluir um título auto-explicativo, na língua do texto, numerado em algarismo arábico, alinhado na margem esquerda e posicionado logo acima da figura. A fonte deve estar logo abaixo da figura. Aqui incluem-se, gráficos, fotografias (nítidas e com contraste), desenhos, etc.

- As tabelas dvem suplementar e não duplicar o texto, numeradas em algarismos arábicos. O título deve ser auto-explicativo, na língua do texto, alinhado na margem esquerda e posicionado acima da tabela. A fonte deve estar logo abaixo da tabela. 
As Referências Bibliográficas no texto devem ser citadas de forma corrida, segundo as normas da ABNT. Recomenda-se evitar citação de resumos simples, somente citando resumos expandidos de Congressos ou de outro evento científico de mesma natureza.

\section{LISTA DE REFERÊNCIAS}

Toda a literatura citada ou indicada no texto deverá ser listada em ordem alfabética. Artigos em preparação ou submetidos à avaliação não deverão ser incluídos nas referências. A formatação das referências deve seguir o padrão estabelecido pela Associação Brasileira de Normas Técnicas (ABNT) em "Regras Gerais de Apresentação" - NBR-6023, de agosto, 2002.

\section{Exemplos de referências}

Os exemplos a seguir não devem ser considerados como referências reais, pois alguns tiveram elementos adicionados a título de exemplificação.

\section{Livros}

SOBRENOME, Inicial nome. Título. Cidade da editora: Editora, Ano de publicação.

\section{Exemplo:}

REID, D. Sustainable development: an introductory guide. 1. ed. London: Earthscan, 1995.

\section{Capítulos de livro}

SOBRENOME, Inicial do nome. Título. In: SOBRENOME do ORGAZINADOR, Inicial do nome (Org.). Título da obra. Cidade da editora: Editora, Ano de publicação, páginas.

Exemplo:

ALMEIDA, L. T. Comércio e meio ambiente nas negociações multilaterais. In: BRAGA, A. S.; MIRANDA, L. C. (Org.). Comércio e meio ambiente: uma agenda positiva para o desenvolvimento sustentável. Brasília: MMA/SDS, 2002. p. 97-134.

\section{Artigos em periódicos}

SOBRENOME do autor, Inicial. Título do artigo. Título da revista, volume, número, páginas do artigo, ano de publicação.

Exemplo:

ANYANWU, C. N. The technique of participatory research in community development. The Community Development Journal, v. 23, n. 4, p. 11-15, 1988. 


\section{Trabalho apresentado em evento}

SOBRENOME do autor, Inicial do nome. Título. In: EVENTO, Ano do evento, Cidade do Evento. Anais, página. Disponível em: <hiperlink $>$. Acceso em: data (formato Dia, mês, ano).

Exemplos:

SOUZA, L. S.; BORGES, A. L.; REZENDE, J. O. Influência da correção e do preparo do solo sobre algumas propriedades químicas do solo cultivado com bananeiras. In: REUNIÃO BRASILEIRA DE FERTILIDADE DO SOLO E NUTRIÇÃO DE PLANTAS, 21., 1994, Petrolina. Anais... Petrolina: EMBRAPA, CPATSA, 1994. p. 3-4.

ANDRADE, T. Inovação tecnológica e meio ambiente: dando um passo acima. In: ENCONTRO DA ASSOCIAÇÃO NACIONAL DE PÓS GRADUAÇÃO E PESQUISA EM AMBIENTE E SOCIEDADE, 2., 2004, Indaiatuba, SP. Anais... Indaiatuba: ANPPAS 1 CD-ROM.

ANDRADE, T. Inovação tecnológica e meio ambiente: dando um passo acima. In: ENCONTRO DA ASSOCIAÇÃO NACIONAL DE PÓS GRADUAÇÃO E PESQUISA EM AMBIENTE E SOCIEDADE, 2., 2004, , Indaiatuba, SP. Anais... Indaiatuba: ANPPAS 2004. Disponível em: <http://www.anppas.org.br/encontro_anual/encontro2/GT/GT01/thales. pdf >. Acesso em: 31 ago. 2007.

\section{Dissertações, teses e relatórios}

SOBRENOME, Inicial do nome. Título. Ano, Número de páginas. Dissertação - Centro, Universidade, Cidade.

Exemplo:

SERRANO, C. M. T. A invenção do Itatiaia. 1993. 179 f. Dissertação (Mestrado em Sociologia) - Instituto de Filosofia e Ciências Humanas, UNICAMP, Campinas.

\section{Trabalhos em meio-eletrônico}

Exemplo:

SÃO PAULO (Estado). Secretaria do Meio Ambiente. Tratados e organizações ambientais em matéria de meio ambiente. In: . Entendendo o meio ambiente. São Paulo, 1999. v. 1. Disponível em: <http:://www.bdt.org. br/sma/entendendo/atual.htm>. Acesso em: 8 mar. 1999.

\section{Artigos de periódico em meio eletrônico}

Exemplos:

AIKAWA, N. Visión Histórica de la Preparación de la Convención Internacional de la UNESCO para la Salvaguardia del Patrimonio Cultural Inmaterial. Museum Internacional. Patrimonio Inmaterial. Paris, UNESCO, 
n. 221-222, p. 140-155, 2003. Disponível em: <http://portal.unesco.org/ culture/en/ev.php>. Acesso em: 5 set. 2006.

JOLY, C. A. Acesso a recursos genéticos, repartição de benefícios e proteção dos conhecimentos tradicionais. Biota Neotrop., v. 5, n. 1, p. 3-3, 2005. Acesso em: 26 jun. 2006. Disponível em: <http://www.scielo.br/scielo. php?script $=$ sci_arttext $\&$ pid $=$ S1676=06032005000100001-\&lng=en\&nrmiso $>$.

ISSN 1676-0603. online.

Legislação BRASIL - SNUC. Lei no 9.985 de 18 de julho de 2000. Institui o Sistema Nacional de Unidades de Conservação e dá outras providências. Brasília, DF, 2000.

O envio espontâneo de qualquer colaboração implica automaticamente a cessão integral dos direitos autorais ao INCT-PPED. A revista não se obriga a devolver os originais das colaborações enviadas. 
Desenvolvimento em Debate 